\title{
The Impact of the Old Age Grant on Rural Households in Nkonkobe Municipality in the Eastern Cape Province of South Africa
}

\author{
Prof. Pius Tanga Tangwe \\ University of Fort Hare \\ Email: ptangwe@ufh.ac.za \\ Priscilla Gutura \\ University of Fort Hare \\ Email: priscillagutura@gmail.com
}

Doi:10.5901/mjss.2013.v4n13p627

\begin{abstract}
The aim of this study was to explore the socio-economic impact of old age grant on rural households in the Eastern Cape Province, South Africa. The findings of this paper are based on in-depth interviews conducted with twenty-five beneficiaries of the Old Age Grant (OAG) in Alice. They were purposively selected to gauge the impact of this grant on their households. The results show that the OAG plays a vital role in households by contributing significantly to household expenditure. This grant assists in the provision of food, payment of school fees, transport, rent and water as well as the purchase of uniforms, books, electricity and other necessities. The OAG which was intended as a poverty relief programme for the aged has turned into a poverty alleviation programme for rural households. When they live together with other generations these pensioners become the primary caregivers in the household and they act as breadwinners by looking after their unemployed children, orphans, grandchildren and other relatives.
\end{abstract}

Keywords: Old Age Grant, socio-economic impact, rural households, poverty, household expenditure

\section{Introduction}

It is noteworthy that ageing reduces one's capacity to work and to earn. In many African countries, the traditional safety net for the elderly was the extended family, especially their own children. As Schwarz (2003:1) points out, "the extended family is not and was not, a perfect safety net especially when children are too poor to support their parents". South Africa's social safety nets for the African elderly had largely been neglected during apartheid. Nevertheless, South Africa was the first country to institute a state pension in Africa and it boasts the longest history as a welfare state, although it has the shortest history of universal democratic elections (Pelham, 2007). The state pension was instituted in 1928, carried forward by the Coalition Pact Government and reformed under the National Party's apartheid rule from 1948. The government of South African from 1994 onwards committed itself to redirecting resources towards social sectors and social spending in areas previously discriminated against on racial grounds. The state OAG is now a non- contributory scheme financed from the national budget and general taxes. It is a social grant paid to an aged person in terms of Section 10 of the Social Assistance Act (No13 of 2004).

Eligibility for payments is determined by age and a means test. Women aged 60 and older are eligible for the pension. Initially, men did not become eligible until the age 65. In 2008 a law was passed to equalize the age of eligibility between men and women by 2010. This was done in stages and the male age of eligibility immediately dropped to 63 (SASSA, 2008). According to SASSA (2010), the age of eligibility for the Grant for Older Persons as from April 2010 has been set at 61 and 62 years for men and females 60 years provided they met the stipulated criteria. At a current value of R1260 per month it has, by developing country standards, comparatively generous eligibility thresholds and benefit levels (approximately double the per capita median income for Africans) (SASSA, 2013). The expenditure for 2013/14 on the OAG is R30 billion. However, the current means test for the old age grant will be phased out in order to simplify administration and prevent the exclusion of vulnerable individuals as announced in the Budget Speech in February 2013 by the Finance Minister Pravin Gordhan. He said, "All citizens over a designated age will be eligible for the grant which will simplify its administration and address the disincentive to save that arises from the present means test," (Gordhan, 
2013).

Nevertheless, most of the beneficiaries of OAG are found in rural regions whilst a relatively high number are also either married or widowed (SASSA, 2012). Between 1997 and 2006, numbers of OAG beneficiaries rose by an annual average of 2.7 percent, from a total of 1.7 to 2.1 million people, or about five percent of the total population. The total number of beneficiaries of the OAG amounted to 2,873,197 in March 2013.Table 1 shows the number of OAG recipients by province, as at 30 March 2013.

Table 1: Total Number of OAG beneficiaries according to provinces

Source: SASSA (2013)

\begin{tabular}{|l|c|c|}
\hline \multicolumn{1}{|c|}{ Province } & Number of OAG beneficiaries & Percentage \\
\hline Eastern Cape & 509612 & 18 \\
\hline Free State & 172103 & 5 \\
\hline Gauteng & 424892 & 15 \\
\hline KwaZulu Natal & 590959 & 21 \\
\hline Limpopo & 395264 & 14 \\
\hline Mpumalanga & 227239 & 7 \\
\hline North West & 217274 & 6 \\
\hline Northern Cape & 74919 & 3 \\
\hline Western Cape & 260935 & 9 \\
\hline Total & $\mathbf{2 8 7 3 1 9 7}$ & $\mathbf{1 0 0}$ \\
\hline
\end{tabular}

The figures suggest that service delivery in terms of social grants is directed where it is needed most in rural poverty stricken areas of South Africa. The table shows that Kwazulu-Natal (KZN) accounts for the highest percentage (21\%) followed by the Eastern Cape (18\%), then Limpopo (15\%). The region that accounts for the lowest percentage of old age grant recipients is the Northern Cape (3\%). Statistics on the number of old age beneficiaries from 2006 to January 2013 shows that an annual average growth rate of $7.5 \%$ has been evident. This indicates that the number of old age beneficiaries has risen significantly over the years as compared to other social grant beneficiaries.

The aim of this study therefore, was to explore the socio-economic impact of the old age grant on households in rural households in the Eastern Cape Province. The specific objectives were to find out what the old age grant money is used for by beneficiaries; and to explore the living conditions of households and the impact of the old age grant on the different persons staying in the same household with the old age grant beneficiary.

\section{Literature Review}

This section looks at prior research on the impact of social grants in South Africa and discusses the theoretical framework that guided the study.

\subsection{Overview of literature}

Much of the earlier work on the impact of social grants on poverty focused on the success of the old age pension (Tanga, 2008) and the importance of this source of income for household security and household food security (Woolard et al, 2010; Van Der Berg, Siebrits and Lekezwa, 2010). There is a body of evidence that highlights the role of social assistance in poverty alleviation in South Africa (Neves et al, 2009; Grant et al, 2010; Lekezwa, 2011 and Demba, 2012). A recent research carried out by Tanga and Gutura (2013) assured the positive impact on the participation in the labour market by female beneficiaries of the Child Support Grant. Lalthapersad-Pillay (2008) however, argued that the importance of old age grant can be properly gauged only by taking into consideration and ascertaining the contribution of the elderly and its influence on the well being of the elderly themselves and other household members. For instance, the research findings on the study conducted by Financial Diaries (2012) revealed that social grants are a significant portion of household income in Langa and Lugangeni towns. The study further purports that for those receiving the old age grant, this income tended to represent a large portion of household income as compared to other social grants. Moreover, Barrientos and Sherlock Lyod (2011) using a comparative study, argue that pensions in South Africa and Brazil have had a significant impact on reducing poverty among older people and their households. In both countries, noncontributory pensions function more as an income transfer to poorer households rather than individual retirement 
income. Therefore, the wider contributions made by older people is significant. For example, a quarter of those surveyed in South Africa and a third in Brazil said they were in a position to substantially help other household members in their daily lives.

A more critical position was inferred by Kasere (2012) in his study which used statistical data collected by the South African government as well as more localised evidence gathered in the Eastern Cape town of Grahams town to ascertain the significance of old age pensions for poverty reduction. He found out that while there was some evidence to suggest that pensions contribute to poverty reduction, this did not translate into poverty alleviation. In fact, there was some unevenness in the impact of pensions on poverty. In this regard, the decision-making structures in poor households regularly influenced the way pension money was allocated and used within households. The study highlighted that the grant money was normally shared in extended households, such that the pension did not simply benefit the recipient but the recipient's household as a whole. Therefore, as reinforced by Department of Social Development (2006), the benefits of the OAG indirectly accrue to a much larger number of people in the guise of support to dependents.

Another perspective was advanced from a study of older South African households conducted by Moller (2011) which suggests that old age grants and other social assistance make the difference between fortune and misfortune for many vulnerable households. The study traced three groups of older households: black households resident in the former rural 'homelands' of the Eastern Cape Province, and two groups of urban black and coloured households in Cape Town and concluded that social pensions play an important role in boosting the fortune and well-being of beneficiaries and their households. It seemed in this study that securing a regular pension income was still the route to good fortune for rural households.

Above all, government transfer to the elderly is a sure way of targeting poverty among the elderly. However, Kalula (2009:136) highlights the fact that there are unsolved issues concerning older persons that need to be addressed. These include; poverty and lack of basic needs; abuse of pensioners by their own children; being remembered "only at election time when offered assistance by politicians as a campaign tool" and being affected by HIVIAIDS as primary care-givers for the sick looking after orphans and sick adult children. The review of literature has highlighted that the state old age pension is the key plank of South Africa's social safety net, that these pensions are well targeted to the poor, and, because of the large number of three-generation and skipped-generation households in South Africa, they reach many poor children.

\subsection{Theoretical framework}

In order to understand the issue of old people receiving OAG providing for younger generations in the households, this study is anchored in the social exchange theory. Social exchange theory emerged within family sciences in the latter part of the twentieth century, first being considered in a meaningful way in the early 1960s. It arose out of the philosophical traditions of utilitarianism, behaviorism, and neoclassical economics. Drawing upon economic cost-benefit models of social participation, Thilbaut and Kelley (1959), Homans (1961) and Blau (1964) expanded this perception into a view of social behaviour as an exchange and attempted to explain motivations for behaviour, and the balance and structure of exchanges of resources (exchange of goods, material goods and nonmaterial goods). The theory's fundamental principle is that humans in social situations choose behaviors that maximize their likelihood of meeting self interests in those situations. As in economic exchange, the profit that the individual derives from social exchange is equivalent to the difference between rewards and costs. Participants in an exchange of behaviour will continue their exchange only so long as the exchange is perceived as being more rewarding than it is costly. Power resides implicitly in the dependence of the other. If both parties in the exchange relationship are equally dependent upon each other, the relationship may be said to be balanced. When the exchange relation is unbalanced, the exchange partner who is the more dependent hence the less powerful - will attempt to rebalance the relationship and thereby reduce the costs he/she incurs from the exchange.

While key concepts include social rewards and costs, social resources, and social contact, the theory attempts to account for exchange behaviour amongst individuals of different ages as a result of the shift in roles, skills and resources that accompany advancing age. Thus gerontologists in South Africa may apply social exchange theory to explain kin support systems and intergenerational living arrangements. This study thus, integrates exchange theory in explanations of old people receiving OAG providing for younger generations in the households. 


\section{Study Area and Methods}

This section looks at the study area used and the research methodology employed.

\subsection{Description of study area}

The Nkonkobe Municipality is the second largest Municipality in the Amathole District, covering an area of some 3725 $\mathrm{km}^{2}$ with a population density of 43 people per square kilometre (Amathole District IDP, 2012-2017). Alice is the second largest town in the Municipal area. Alice is a service centre and a university town nestled in the Tyume Valley, at the foothills of the Amatole Mountains, at the confluence of the Gaga and Tyume Rivers. Alice is like many other former Bantustan spatial economies - being characterised by extreme underdevelopment, poverty and lack of basic services in surrounding rural areas; a dearth of institutional and technical capacity (outside of the University of Fort Hare that is); and no sustainable economic base. As in so many other rural former Bantustan towns, this has created enormous development challenges for the recently constituted local authorities. But what makes Alice different to so many other rural towns in the former Ciskei is the location of the University of Fort Hare, which has to play a central role in the towns socio-economic revival.

According to statistics provided by the Statistics SA (2011), approximately $80 \%$ of the total population is unemployed. The high unemployment rate includes, economically active population from students, youth, women who do not have access to job opportunities. The data presented by Statistics SA (2011) further indicates that $58 \%$ of households earn less than R500 per month while $77 \%$ less than R1000 per month, comparing that to $41 \%$ of households in Eastern Cape that earn less than R500/month. The Community and Social Services (including Education) sector is the greatest employer in the Municipal area, employing $44 \%$ of the active work force. It is followed by agriculture (13\%) and private households (11\%). It is notable that some $55 \%$ of those employed in Nkonkobe are employed in highly skilled occupations - in the public service and education institutions. However, many households in and around Alice are sustained by social grants, remittances, income from a single wage earner and various small-scale activities.

Based on the above, it becomes clear that the educational and public sectors provide the greatest opportunities for employment and advancement in Alice. A young person is therefore likely to have difficulty in finding employment in Alice. The situation in the district may be due to low levels of skills, especially in the rural areas of Victoria East, where $38 \%$ are largely found in elementary occupations. The picture that is emerging is that there is no technical base whatsoever in the district. The exodus of people of working age has resulted in a higher than average proportion of the population who are either unable to work (older persons and children), or whose work is not remunerated (women whose main work is childbearing and care giving).

\subsection{Research methodology}

The data for the study was therefore gathered in Alice. The sample consisted of twenty-five beneficiaries who were selected based on purposive/judgemental sampling. These participants were interviewed whilst they were queuing on the pay points to withdraw their monthly grant. Only those whose main source of income was OAG were selected. However saturation was reached after interviewing these 25 participants. Using a qualitative design, data were collected through the use of in-depth interviews. An interview guide was used to ensure uniformity in the information obtained from the research participants; this meant that the questions directed at the participants were more or less the same and that the collection of irrelevant information was avoided. The questions in the interview guide were open ended, clear and neutral. They were unbiased to enable the research participants to formulate their responses easily. The collected data were analysed qualitatively based on the key themes that emerged.

\section{Results}

The age of the beneficiaries who participated in the study ranged from 60 to 90 years with a mean age of 70 years. Most of the participants were women (20), with the remaining five (5) being men. During the interview, the participants were asked how many adults lived in their household. The majority of beneficiary indicated that their households had between 1 and 4 adults per household. The beneficiaries were further inquired about the level of education that they had attained and the majority (13) had no schooling, followed by five who only had primary schooling. It was revealed in the study that of all the participants 12 were married, 6 were widowed, 2 divorced, 2 separated and 3 had never been married. 
The results further revealed that the highest source of income in the households was the old age pension. Nevertheless, the first theme that emerged explored the uses of the OAG.

\subsection{Theme 1: Grant money used for groceries and other household needs as well as children's school needs}

Most of the participants (20) indicated that they used the grant to buy food for the entire household, pay school fees, buy uniforms, address health need, buy clothes and pay bills (rent and accounts and for electricity). Of the participants, 23 maintained that they spent money on their household members. However, two said that they only used the money for their well being. Among those who said they used their grant money on other household members one participant highlighted that.

My two daughters were infected by HIVIAIDS and they were unable to go to work. I am staying with them and their children also. Since they are not earning any income except for the Child Support Grant they receive which is small, I use my grant to take care of them. They are my blood I cannot let them suffer.

Furthermore, one participant highlighted that she had elderly granddaughters who gave birth at an early age and after benefiting from a child support grant they would disappear with the money, leaving children to be supported by her. Some highlighted that the children had migrated to urban areas in search of employment, thus leaving their children behind. The rate of unemployment in Alice forced the elderly to assist socio-economically vulnerable family members. One participant said:

This town that we stay in is very small and there are no jobs available. My children have left for Johannesburg and Cape Town to search for employment. They could not take their children along with them so they left them with me their grandmother. So I am taking care of my grandchildren.

In order to obtain the beneficiaries perceptions of the old age grant, they were also given the opportunity, in the interviews, to indicate whether the OAG had enabled them to acquire goods and services that they might otherwise not have been able to afford. This led to the beneficiaries emphasising the affordability of buying food, clothes and paying bills. The majority (19) indicated that it had afforded them a lot in terms of buying food, clothes and paying bills such as electricity and water. One participant said:

Since I started to receive the OAG I am now able to pay for my bills every month. Right now after I have withdrawn my money I am going to buy electricity that will last the whole month. Even the food I can afford to buy the food that can last the whole month and there is no more hunger in my household.

However 6 participants emphasised that the money was not enough to take care of the large number of household members they were living with.

\subsection{Theme 2: Experienced change in the standard of living of household members}

Another theme that emerged when analysing the data was the change of standard of living among the beneficiaries. The participants were asked to describe their standard of living before and after they started receiving the grants. The results show that prior to receiving the OAG, 20 indicated that their standard of living had improved to an average status from having previously been below average. Therefore the results reveal the impact of OAG on the standard of living of beneficiaries and their families. The data presented strong evidence that most of the respondents were very satisfied with the impact of their pension on the household with only 5 respondents who were dissatisfied. When describing her standard of living in the interview, one participant said:

Our living conditions have changed considerably in my family especially with the issue of provision of food. As the head of the household I could not afford to buy healthy food for my big family. My kids and I were dying of hunger but now that we are getting a grant it is better we can afford to buy food that last for a month.

\subsection{Theme 3: Insufficiency of grant money to cater for most basic household needs}

Additionally, one of the themes that emerged was the insufficiency of the grant. Participants were asked if the money was sufficient to meet all their needs. Inspite of the fact that the participants indicated that the grant was making some impacts in their lives, all participants denied that the money was enough to meet all their needs and they wanted the 
government to increase the grant. Even though they had indicated that the money was not enough, when asked if they would survive if the grant was to be terminated, 23 of the participants said that they would not be able to survive whilst only 2 agreed that they would because their working children sent them remittance at the end of each month. One participant said:

The government should not stop giving me the grant because I am too old and weak to work. I do not have anywhere else that I can get the money. I will not survive even my grandchildren will not survive. We all depend on that grant.

\subsection{Theme 4: Large households and HIV/AIDS family members to cater for with grant money}

Moreover, during the interviews another theme that emerged was that the OAG beneficiaries were looking after a lot of people who were staying within the same household. The participants highlighted this as a challenge that they were facing due to the fact that the money was not enough to satisfy their needs as they were looking after a lot of people staying in their households including some adults who were not employed and even their grandchildren. An extreme challenge was noted as one participant said that her son abused her physically because he wanted the money for himself. She indicated that:

My son knows the day when I receive my money so he comes here every night and starts shouting at me that I should give him the money not to buy clothes for my grandchildren and they don't deserve the money but him. When I refuse or ask him why he wants the money he starts beating me up saying am a bad mother and calling me names (sic). But I can't give him the money I have grandchildren to take care of.

The other challenge that was highlighted by the participants was the pressure they go through for looking after the HIVIAIDS patients in their households. Out of the 25 participants, 21 reported that they were taking care of ill household members while 4 were not. The kind of conditions identified included terminal illnesses such as HIVIAIDS, tuberculosis and cancer. One participant said:

I am taking care of my sister who is HIV positive because her husband threw her out of the house when she got seriously ill. She has children in the urban area but they do not send any money to buy her nutritious food because the nurse told me that she needs to eat a healthy diet. So most of the money I use it to buy her fruits, vegetables among other things.

\section{Discussion}

In many developing countries especially in Africa, large extended families often live together. Shared housing may suggest the sharing of other resources, most notably money. A transfer targeted at one demographic group may eventually find itself in the pockets of relatives living in the same household. The South African Government is concerned about the welfare of the elderly, as expressed in the White Paper on Social Welfare, where government pledges commitment to promoting the rights of the elderly in order to protect them and ensure that they are provided with basic needs (South Africa, 1997:50).The rural and urban areas in South Africa are all affected by poverty, unemployment and HIVIAIDS. Because of this socio-economic phenomenon, the old age pension system implemented by the government in 1994 with the aim of alleviating older persons' poverty has become the main source of income for pensioners and household members.

The exchange of support is more likely to be related to affective and non-financial instrumental support, because the majority of the black elderly had the misfortune of being poor throughout the apartheid which had privileged the then young whites rather than the young blacks who are the elderly of today. Elderly blacks live together either in rural or urban areas with their adult children, grandchildren and other family members. In this case, the intergenerational living arrangements in South Africa are becoming almost non-existent because the elderly, who are supposed to be supported by their children or grandchildren, are unfortunately those who take care of other generations (own children and grand children) (Tanga, 2008).

According to Demba (2012), the benefits of pensions are found to be distributed more broadly to all in the household as the majority of poor households in South Africa live in intergenerational households. The OAG not only helps the recipient who is the grandmother or grandfather in the household, but it also benefits the children of the recipients who are unemployed, the grandchildren orphaned through HIVIAIDS, as well as the abandoned children left for the grandmothers to take care of. Barrientos and Lloyd-Sherlock (2011), in their research in Brazil, found that social 
pensions were able to support entire families. Local evidence also shows that older South Africans are consistently investing the little money they had in income generating activities as well as in health and education of other family members (Legido-Quigley, 2006). We therefore argue that, in South Africa, the old age pension is increasingly the sole household income, achier as a lifeline to over two million non-contributory pensioners caring socio-economically for grandchildren, children and other family members who live with them (Department of Social Development, 2009). Rather than creating dependency, social transfers such as old age pensions reduce the dependency of pensioners when pensioners are able to invest their pension capital in small businesses and household members are supplemented with government grants.

Children add a financial burden to households in addition to their duty consumption requirements for food and clothing, they need to attend school. Even if orphans are eligible to receive the government grant that covers their fees, there are additional expenses such as uniforms, books and transport. The fact that almost all the participants indicated that they live with orphans appropriately explains the fact that the regular receipt of the OAG and resultant guaranteed income may better equip beneficiaries to afford to raise orphans. The OAG thereby helped to improve the health status of all the people in the household, not just the direct recipient. The results are consistent with other findings from earlier studies, (Grant et al, 2010), which indicate that the OAG plays a vital role in the health of entire households.

Elderly people in disadvantaged communities play a major role in preserving the health and well-being of their children, family and community. They sustain their contributory role despite imposed-health functional limitations and physical and/or emotional distress. Health services could be redesigned to support their contributory roles and thus enhance their health and well being as well as that of their family and community. This study provides evidence that stereotypical roles of targeted elders are often reversed with the elderly becoming care providers rather than care recipients. A wide range of elderly people contributory actions and recipients who benefit from these actions were identified. The findings of this study demonstrate that the sampled elders make considerable contributions to the wellbeing of their family and community, but these overlap with substantial health problems and impose functional limitations and distressing symptoms.

The money from the old age grant is used to take care of the children in various ways. First, it helps in buying medication, providing good nutrition and care-giving for children who are infected with HIVIAIDS. The elderly in our study, in households affected by the pandemic, reflected that the money helps a lot in catering for the grandchildren who are sick. Our results complement the findings by a study that used panel data from Cape Town to document the role played by aging parents in caring for grandchildren who lose parents due to illnesses such as AIDS (Ardington et al, 2010). The authors quantify the probabilities that older adults and their adult children provide financial support to orphaned grandchildren. The authors find significant transfers of public and private funds to older adults caring for orphans. Findings suggest that the combined public and private safety net in South Africa mitigates many of the consequences older adults could suffer when an adult child dies and leaves behind grandchildren needing care. In households affected by HIVIAIDS, the old age pension contributed towards the expenses which pensioners used while treating ill children, care- giving and any funeral costs. This means that pensioners, with their pension, provide psycho-social and financial care to their household members at the expense of satisfying their own needs.

One significant ongoing challenge is the increasing socio-economic drains on the pensioners' grants from the HIVIAIDS pandemic because of the ever-rising costs of social assistance and social insurance, and the erosion of private savings. The HIVIAIDS scourge adds to pensioner socio-economic responsibilities to extend socio-psychological and economic care to orphaned grandchildren, unemployed children and other household members. This means that the elderly are not able to enjoy the benefits of the OAG, which is intended for their specific wellbeing. Not only affected by HIVIAIDS, as primary care-givers for orphans and sick adult children, for example, the elderly are also being indirectly abused by their own children through neglect and desertion; they are used to take care of grandchildren without the support of the parents, and the money transferred to them for their own needs is used up by their own children. The grant thereby becomes inadequate to satisfy their needs. Given the lack of orphanages in many rural settings, support from extended family and community members offers the best and perhaps only realistic long-term solution to meeting the needs of children whose parents have died. In many cases, grandparents take on a share of the responsibility.

\section{Conclusion}

Receiving an injection of cash with no conditions as to how effectiveness it may be spent allows beneficiaries the flexibility of balancing their short-term and longer-term needs. This study has highlighted that older people living in Alice are no exception to the practice in the country in which they contribute a greater share than previously in caring for the 
household income. This study has provided insights into the impacts of a national cash transfer, collecting valuable evidence for future analysis of the OAG. Since its inception, the OAG has been instrumental in reducing absolute poverty and food insecurity for many vulnerable elderly people and their households. The distributive effects on household members particularly with regard to nutritional status, education and health care significant, improving the lives and well being of the elderly and children; two highly vulnerable groups in South African rural communities. It is noteworthy taking that the social exchange theory used in the study perfectly explains the roles being played by black grandfathers and grandmothers in their households.

Overall, the elderly, especially in the rural areas are overburdened with the care of the household members and, in the end, they are not enjoying the benefits that were intended for their well-being since they cannot work, and their responsibilities make them unable to provide for their own needs. If the notion of care-giving in and by communities for those in need is to be taken seriously, it is most important for the home based care system to receive top priority and funding. However, many of the women are the ones involved in informal home care of relatives, friends or community members. Studies on informal home care givers (Homman et al, 2008 and Kohli, 2012) have shown that many women do not have a choice in taking on the role of caregiver and that this task can be a physical and financial burden. In many cases older women are not only caregivers but also care recipients. It is clear that informal care givers are already an indispensable family and community asset, but that they need support from formal organisations and the state.

Our study supports the fact that the South African government needs to address challenges faced by elderly citizens to allow them to participate more effectively, and at less cost to themselves, in the development of the country. Information generated by more advanced research studies could help improving strategies for managing the impact of old age pension in pensioner households. There is a need to support elderly people who are taking care of HIVIAIDS people by coordinating government, NGO and private sector efforts because, as this study has demonstrated, the elderly are caring for, buying food and medication for the sick and orphaned household members instead of satisfying their own needs.

\section{References}

Amathole District IDP Plan 2012- 2017. [Online] Available: www.amathole.gov.za/attachments/../final\%20idp\%202012-2017.pdf (April 24, 2013).

Ardington, C., Case, A., Islam. M., Lam, D., Leibbrandt, M., Manendez, A. and Olgiati, A. (2010). The impact of AIDS on intergenerational support in South Africa: Evidence from the Cape Area Panel Study. Res Aging Journal, 32 (1), 97-121.

Barrientos, E. and Llyod-Sherlock, P. (2011). Non-contributory pensions and poverty prevention: A comparative study of Brazil and South Africa. London: IDPM\& Help Age International.

Blau, P. M. (1964). Exchange and power in social life. New York, Wiley.

Demba, J. J. (2012). Overcoming poverty in old age: Social security provision in Lesotho, South Africa and Zimbabwe. Revisited. Journal of International Social Work, 5: 1-12

Department of Social Development. (2006). Linking social grants beneficiaries to poverty alleviation and economic activity. Discussion Document. Pretoria, Department of Social Development.

Department of Social Development. (2009). Progress Report. [Online] Available: http://www.socdev.gov.za/Documents/2009/April/progr .PDF (February 12, 2013).

Financial Diaries. (2012). Grant recipients households. How do they manage their money? [Online] Available: www.financialdiaries.com (May 14, 2013).

Grant, D., Grant, F. C., Dependency, C., and Veterans, W. (2010). Social Grants in South Africa. Paper presented at Inequalities in Emerging Economies: What Role for Social Policies? ELSA and EU Conference 19 May.

Gordhan, P. (2013). Budget Speech. Republic of South Africa, Pretoria: Government Printers.

Homans, G. C. (1961). Social behaviour as exchange. American Journal of Sociology, 63(6), 597-606.

Kalula, M. 2009. Investigating the socio-economic impact of the old age pension in the pensioner household within selected areas of the Eastern Cape. CPUT theses \& Dissertations. Paper 57. [Online] Available: http://dk.cput.ac.za.td_cput/57 (June 16, 2013).

Kasere, G. F. (2012). Cash Transfers and poverty reduction in South Africa: A case study of old age pensions. Master's Thesis. Rhodes University.

Kohli, R., Purohit, V., Karve, L., Bhalerao, V. and Karvande, S. (2012). Caring for Caregivers of People Living with HIV in the Family: A Response to the HIV Pandemic from Two Urban Slum Communities in Pune, India. PLoS ONE Journal, 7(9).

Lalthapersad- Pillay, P. (2008). The poverty Alleviation Impetus of the Social Security System in South Africa. Africa Institute of society. [Online] Available: http://www.sabinet.co.za/abstracts/afrins/afrins_v37_n4_a2.html> (March 14, 2013).

Legido- Quigley, H. (2006). The South African Old Age Pension: Exploring the role poverty alleviation in the households affected by HIVIAIDS. Unpublished paper. $4^{\mathrm{TH}}$ International research conference on Social Security. Antwerp: 5-7 May.

Lekezwa, B. L. (2011). The impact of social grants as Anti- Poverty Policy instrument in South Africa: An Analysis using Household Survey Theory to Determine Intra-Household allocation of unearned income. Masters Dissertation: University of Stellenbosch. 
Moller, V. (2011). Perceptions of fortune and misfortune in households of social pensions and the good life. Institute of Social and Economic research. Rhodes University.

Neves, D., Sampson, M., Van Niekerk, I., Hlatshwayo, S. and Du Toit, A. (2009). The use and effectiveness of social grants in South Africa. Research Report to the FinMark Trust. Cape Town: Institute for Poverty, Land and Agrarian Studies (PLAAS) and Economic Policy Research Institute (EPRI). [Online] Available: www.finmarktrust.org.zal.../getfile.aspx?...\%20The\%20use \%20and\%20effectiveness\%20of\%20social\%20grants\%20in (May 13, 2013).

Pelham, W. (2007). The politics behind the non-contributory old age social pensions in Lesotho, Namibia and SouthAfrica. Chronic Poverty Research Centre. CPRC Working Paper 83.

Schwarz, A. (2003). Old age security and social pensions. Geneva, World Bank.

South Africa. (1997). Social Welfare White Paper-Principles, guidelines, recommendations, proposed policies and programmes for developmental social welfare in South Africa. Tshwane, Government Printers.

South African Social Security Agency (SASSA). (2008). Annual statistical report on social grants. [Online] Available: www.sassa.gov.za (July 6, 2013).

South African Social Security Agency. (2010). Strategic Plan 2010/11-2012/13. [Online] Available:www.sassa.gov.za (July 6, 2013).

South African Social Security Agency. (2012). Annual statistical report on social grants. [Online] Available: www.sassa.gov.za (July 6, 2013).

South African Social Security Agency (SASSA). (2013). Annual statistical report on social grants. [Online] Available:www.sassa. gov.za (July 7, 2013).

Statistics South Africa. (2011). South African Statistics 2011. [Online] Available: http://www.statssa.gov.za/publications ISAStatistics/SAStatistics2011.pdf (May 10, 2013)

Tanga, P.T. (2008). The impact of Old Age Pension on Households and Social Relationships. Review of Southern African Studies, 12 (1 \& 2), 184-215.

Tanga P. T. and Gutura, P. (2013). The impact of Child Support Grant on the labour market participation by femalebeneficiaries. Social Work/Maatskaplike Werk, 44 (2), 128-145

Thilbaut, J.W. and Kelley, H. (1959). The social psychology of groups. New York: Wiley.

Van der Berg, S., Siebrits, K. and Lekezwa, B. (2010). Efficiency and equity effects of social grants in South Africa. Working Papers. 15/2010. Stellenbosch University, Department of Economics.

Woolard, I., Klasen, S. and Haartgen, K. (2010). The evolution and impact of Social Security in South Africa. Paper prepared for the Conference on Promoting Resilience through Social Protection in Sub-Saharan Africa, organized by the European Report of Development in Dakar, Senegal, 28-30 June. 
